\title{
PENGEMBANGAN BUKU AJAR BERBASIS SCIENTIFIC APPROACH PADA MATA PELAJARAN AKUNTANSI PERBANKAN KELAS XI PERBANKAN DAN KEUANGAN MIKRO SMK NEGERI 1 KALITENGAH LAMONGAN
}

\author{
Vivi Dwi Triska ${ }^{1}$ Rochmawati $^{2}$ \\ Prodi Pendidikan Akuntansi, Fakultas Ekonomi, Universitas Negeri Surabaya \\ ${ }^{1}$ vivitriska16080304022@mhs.unesa.ac.id, ${ }^{2}$ rochmawati@unesa.ac.id
}

\begin{abstract}
The application of the Revised K13 requires learning devices that act as learning resources, one of which is textbooks. In class XI Banking and Microfinance in the banking accounting subject, there are no textbooks in accordance with the applicable curriculum. The purpose of this development research is to develop and create products in the form of textbooks based on the banking accounting scientific approach for class XI students of Banking and Microfinance at SMK Negeri 1 Kalitengah Lamongan based on the 2014 BSNP standards. In this study also tested the validity of the feasibility of textbooks by students expert. The model used in this development research is the 4D model which includes the stages of define, design, develop, and disseminate. However, this research did not reach the dissemination stage, due to limited time and cost. The results showed the feasibility of presenting material, language, and graphics with a percentage of each component, namely 93.56\%, 92.37\%, and 98.1\%. Therefore, the Banking Accounting textbook is very feasible to use.
\end{abstract}

Key Words: Textbooks, Scientific Approach, Banking Accounting

\section{Pendahuluan}

Pendidikan merupakan salah satu tindakan untuk perbaikan pada kualitas Sumber Daya Manusia (SDM). Hal serupa disampaikan oleh Hapsari, Ornela; Hariyadi, Sugeng; Prihastuty (2014) menyatakan bahwa Sumber Daya Manusia yang diunggul tidak terpelas dari pendidikan. Dalam Undang-Undang No. 20 Tahun 2003 telah dijelaskan bahwa yang dimaksud pendidikan adalah usaha secara sadar serta telah direncanakan yang dilakukan dengan maksud untuk menciptakan suatu keadaan yang kondusif pada proses kegiatan pembelajaran agar peserta didik dapat aktif dalam menggali kemampuannya dengan tujuan untuk memiliki spiritual keagamaan yang kuat, pengelolaan pada diri sendiri, pribadi yang baik, intelektual, akhlak terpuji, serta kemahiran lain untuk dirinya sendiri, masyarakat, bangsa, dan negara. Dalam dunia pendidikan diperlukan adanya dukungan dari komponenkomponen yang terdapat pada sistem pendidikan. Salah satu dari komponen tersebut adalah kurikulum. Kurikulum menjadi pedoman utama dalam pendidikan. Puspita Ratih \& Hakim (2018) menyatakan bahwa di Indonesia utama yang terdapat dalam bidang pendidikan adalah kurikulum. Kurikulum yang digunakan di satuan pendidikan telah dilakukan pembaruan dengan berbagai proses revisi dengan tujuan untuk perbaikan dan peningkatan kualitas pendidikan. Perkembangan pada kurikulum yang ada merupakan cara yang dilakukan oleh pemerintah untuk mengembangkan pendidikan (Wulandari 2019). Saat ini kurikulum yang diterapkan di Negara Indonesia adalah kurikulum 2013 edisi revisi yang berlaku secara nasional. Kurikulum 2013 dianggap sesuai dengan paradigma pembelajaran pada abad 21 . Dalam pelaksanaan pembelajaran pada kurikulum tersebut perlu adanya dukungan berupa pendekatan dan sumber belajar. Sebagaimana yang telah dikemukakan oleh Mulyasa (2018)

DOI: 10.33603/ejpe.v9i1.4574 
bahwa pada Kurikulum 2013 Revisi harus menggunakan model, strategi, metode, teknik, dan pendekatan yang berorientasi pada peserta didik.

Pada Kurikulum 2013 Revisi diterapkan pendekatan pembelajaran yang terdiri atas lima fase atau yang dikenal dengan pendekatan saintifik (Daryanto, 2014). Pendekatan saintifik dianggap mampu untuk memenuhi pengimplementasian pada Kurikulum 2013 Revisi. Karena pada kurikulum tersebut pendidik diharuskan untuk melakukan kegiatan pengembangan pada proses pembelajaran melalui pengintegrasian empat hal esensial diantaranya Penguatan Pendidikan Karakter (PPK), Literasi, Keterampilan Abad 21 atau dikenal dengan istilah 4C (Communication, Collaboration, Critical Thinking and Problem Solving, Creativity and Innovation), serta Higher Order Thinking Skill (HOTS). Selain itu pendekatan saintifik juga ditujukan untuk mengenalkan dan memahamkan materi kepada peserta didik dengan menggunakan pendekatan ilmiah. Kegiatan belajar mengajar dengan pendekatan saintifik menggunakan dasar kaidah ilmiah yang diharapkan mampu menciptakan peserta didik yang dapat berpikir secara kritis, analitis, memenuhi syariat ilmu pengetahuan, dan sesuai dengan keadaan yang ada (Kemendikbud, 2014). Peserta didik pada tingkatan yang lebih tinggi dalam proses pembelajarannya perlu diterapkan pendekatan saintifik, hal itu dikarenakan pendekatan tersebut berpusat pada ranah keterampilan yang diperlukan untuk persiapan diri memasuki bidang kerja.

Pada satuan pendidikan jalur formal yang memiliki visi dan misi memiliki peserta didik yang berpotensi dan siap untuk melanjutkan ke dunia kerja sesuai dengan bidang keahliannya adalah Sekolah Menengah Kejuruan (SMK). Peserta didik pada tingkat menengah kejuruan dituntut untuk mampu dalam memahami teori serta keterampilan yang telah didapatnya dalam rangka untuk membekali diri memasuki dunia kerja sesuai bidangnya. Penyesuaian konsep dan segala perangkat pembelajaran menjadi hal penting untuk mencapai hal tersebut. Perangkat pembelajaran yang baik akan berimbas pada suksesnya kegiatan pembelajaran (Muqodas, Sumardi, \& Berman, 2015). Perangkat pembelajaran terdiri atas beberapa jenis dan memiliki peran dalam pelaksanaan kegiatan pembelajaran. Salah satu jenis dari perangkat yang dimaksud adalah bahan ajar. Nasution (2013) menyatakan bahwa pemanfaatan bahan ajar sangat membantu pendidik dalam menyampaikan informasi. Pemilihan pada bahan ajar yang efektif dapat membantu untuk mencapai tujuan pendidikan dan meningkatkan pengetahuan peserta didik. Hal serupa dinyatakan oleh Putra (2020) bahwa tujuan dari pembelajaran dapat dicapai dengan menggunakan sebuah bahan yang diimplementasikan saat kegiatan pembelajaran sebagai sumber belajar.

Menurut Prastowo (2015) dijelaskan bahwa yang dimaksud bahan ajar merupakan segala bentuk bahan (baik berupa informasi, alat, maupun teks) yang dibuat dan disusun secara sistematis serta dapat menampilkan perwujudan secara utuh atas kompetensi yang akan dipelajari oleh peserta didik dalam proses pembelajaran. Ada banyak kategori untuk bahan ajar, salah satunya berdasarkan atas bentuk. Bahan ajar tersebut berbentuk cetak, dengar, pandang dengar, interaktif. Pemilihan bahan ajar didasarkan atas kebutuhan. Dalam penelitian yang dilakukan oleh Ma'sum (2019) menyatakan bahwa perlu dilakukan pemilahan terhadap bahan ajar dengan tujuan untuk mempermudah proses belajar dalam hal 
ini pada jenjang pendidikan tingkat SMK. Bahan ajar yang dipergunakan di sekolah dalam bentuk buku cetak. Menurut Prastowo (2015), buku adalah lembaran dari beberapa kertas yang dijilid, baik yang telah diisi dengan tulisan maupun yang masih kosong. Sedangkan buku ajar didalamnya terdapat tulisan tentang maklumat suatu bidang. Buku ajar menjadi pendukung dalam kegiatan pembelajaran yang berisi tentang materi serta dilengkapi dengan soal-soal latihan. Menurut Nasution (Prastowo, 2015) buku adalah salah satu jenis alat yang banyak dipakai dibandingkan jenis yang lain.

SMK Negeri 1 Kalitengah Lamongan adalah Sekolah Menengah Kejuruan yang terletak di Kabupaten Lamongan yang menerapkan Kurikulum 2013. Bersumber pada hasil pengamatan dari peneliti diperoleh informasi diantaranya: (1) bahan ajar yang tersedia sebagai penunjang kegiatan pembelajaran berupa LKS yang termasuk dalam terbitan lama dan belum memenuhi kriteria sesuai dengan ketentuan kurikulum yang berlaku, (2) bahan ajar hanya dipegang oleh pendidik atau guru saja, (3) selama proses pembelajaran peserta didik hanya dijelaskan dengan metode ceramah yang tidak sesuai dengan pengimplementasian pada Kurikulum 2013, dan (4) terbatasnya bahan ajar yang ada membuat peserta didik cenderung pasif saat kegiatan pembelajaran sedang berlangsung.

Untuk mengatasi permasalahan yang terjadi di SMK Negeri 1 Kalitengah Lamongan, maka diperlukan adanya pengembangan terhadap bahan ajar Akuntansi Perbankan yang disesuaikan berdasarkan Kompetensi Dasar. Vitasari \&Rohayati (2018) menyatakan bahwa pembelajaran pada kurikulum 2013 harus kontributif dengan bahan ajar, karena jika tidak sepadan akan berdampak pada tidak maksimalnya proses pembelajaran di kelas. Selain itu dalam penelitiannya Novita (2018) menyatakan bahwa bahan ajar memiliki posisi sebagai representasi dari penjelasan guru dalam kegiatan pembelajaran. Bahan ajar diekspansi dalam bentuk buku ajar. Buku ajar merupakan bahan ajar serta sumber untuk belajar yang sangat mudah ditemukan dan banyak digunakan. Agustin Nur Raafi \& Hakim (2018) menyatakan bahwa buku ajar buku yang dibuat oleh prakarya sebagai sumber pengetahuan untuk menunjang proses pembelajaran kea rah yang bermutu. Dalam penggunaannya peserta didik hanya perlu membaca dan memahami isi materi yang tercantum dalam buku ajar tersebut. Buku ajar Akuntansi Perbankan dikembangkan dengan menggunakan pendekatan scientific approach yang sesuai dengan pengimplementasian Kurikulum 2013 Revisi. Buku ajar juga dilengkapi dengan konten-konten tambahan sehingga dapat memotivasi peserta didik untuk mempelajari materi Akuntansi Perbankan. Pertiwi (2019) mengemukakan bahwa bahan ajar dengan daya tarik tinggi sangat diperlukan untuk peserta didik agar mereka termotivasi untuk membacanya. Penyusunan buku ajar ini mencakup keseluruhan sintak yang terdapat pada pendekatan scientific approach. Dengan adanya buku ajar diharapkan dapat menjadi penunjang kegiatan pembelajaran dalam rangka proses penyampaian materi kepada peserta didik sehingga tujuan dari kegiatan pembelajaran akan tercapai. Hal tersebut selaras dengan pendapat Arlianty, Febriana, \& Diniaty (2017) yang menyatakan bahwa penerapan pendekatan saintifik dapat meningkatkan pencapaian proses belajar. Selain itu pendapat lain yang mendukung adalah penelitian dari Firman, Baedhowi, \& Murtini (2018) yang menyatakan bahwa penggunaan bahan ajar dengan menggunakan pendekatan scientific 
approach mampu untuk meningkatkan hasil dari proses belajar pada peserta didik. Buku ajar Akuntansi Perbankan yang dibuat peneliti dilengkapi soal latihan dengan tipe soal Higher Order Thinking Skill (HOTS) sebagai bentuk peningkatan keterampilan peserta didik khususnya pada SMK yang mengutamakan kreativitas dan kemampuan mandiri. Mei, Yunos, Othman, Hassan, \& Tze (2012) menyatakan bahwa dengan mempelajari HOTS akan dapat meningkatkan pikiran individu, mengarah pada produksi varietas alternatif, ide, tindakan, solusi, dan desain. Oleh sebab itu peserta didik diharuskn belajar dan menggunakan HOTS untuk menghasilkan ide agar mereka dapat menyelesaikan tugasnya lebih efektif.

Penelitian terdahulu yang relevan adalah penelitian dari Indriyani \& Hakim (2019) yaitu "Pengembangan Buku Ajar Berbasis saintifik Pada Mata Pelajaran Akuntansi Perbankan Syariah Kelas XII Semester II SMK Negeri 2 Kota Mojokerto” yang kemudian disimpulkan bahwa buku ajar tersebut sangat layak untuk dimanfaatkan. Selain itu penelitian yang dilaksanakan oleh Masithoh (2018) yaitu "Teachers Scientific Approach Implementation in Inculcating the Students " Scinetific Attitudes" yang menunjukkan hasil bahwa kegiatan pembelajaran dengan pendekatan saintifik memiliki tujuan khusus untuk mencapai prestasi belajar peserta didik. Lebih lanjut penelitian oleh Margana \& Widyantoro (2017) yaitu "Developing English Textbooks Oriented to Higher Order Thinking Skills for Students of Vacational High Schools in Yogyakarta" yang menunjukkan hasil penelitian bahwa buku teks Bahasa Inggris yang berisi soal-soal HOTS mendapatkan respon positif dari peserta didik karena dapat menambah keterampilan berpikir tingkat tinggi.

Sesuai latar belakang yang disampaikan, maka peneliti bermaksud untuk membuat studi penelitian yang bejudul "Pengembangan Buku Ajar Berbasis Scientific Approach Pada Mata Pelajaran Akuntansi Perbankan Kelas XI Perbankan dan Keuangan Mikro SMK Negeri 1 Kalitengah Lamongan".

Adapun tujuan dari penelitian diantaranya untuk melakukan analisis terhadap proses dan kelayakan atas pengembangan buku ajar Akuntansi Perbankan. Buku ajar yang akan dikembangkan memuat materi dan soal latihan pada setiap Kompetensi Dasar (KD). Isi materi dalam buku ajar adalah materi pada semester ganjil yang dimulai dari KD 3.1 sampai KD 3.7. Konten-konten tambahan yag terdapat dalam buku ajar diantaranya adalah Mind Map, Science Window, Mini Quiz, Key Point, QR Code, dan Glossarium. Buku ajar yang dibuat berukuran A4 dengan berat $80 \mathrm{gsm}$ (gram per square meter) untuk bagian isi, dan art paper 150 gsm (gram per square meter).

\section{Metode Penelitian}

Klasifikasi penelitian termasuk dalam penelitian pengembangan (Research and Development) atau $R \& D$ yang merupakan tindakan secara ilmiah untuk memelajari, mengonsep, membuat, dan memverifikasi kelayakan atas produk yang dibuat dalam penelitian (Sugiyono, 2018). Disampaikan oleh Mulyatiningsih (2013) bahwa bentuk dari penelitian pengembangan pada bidang pendidikan terdiri dari model pembelajaran, media dan peralatan penunjang pembelajaran, buku ajar, perangkat pembelajaran, kurikulum, kebijakan sekolah, dan lain sebagainya. Model pengembangan yang diinterpretasikan oleh peneliti 
adalah model 4-D atas anjuran dari Thiagarajan, Semmel, dan Semmel (Trianto, 2015). Terdapat empat tahapan yang akan dilakukan peneliti dengan tujuan untuk mengimplementasikan penelitian pengembangannya. Tahap awal atau yang pertama yaitu pendefinisian (define), tujuannya untuk menetapkan dan merumuskan syarat yang terdapat dalam kegiatan pembelajaran, didahului dengan melakukan berbagai analisis. Berikutnya yaitu menyusun rancangan (design), melakukan penyusunan pada format buku dan dilanjutkan dengan membuat desain awal buku yang kemudian akan menghasilkan prototipe I. Kemudian tahap yang ketiga yaitu pengembangan (develop), dalam tahap ini para ahli akan melakukan telaah terhadap prototipe yang telah dihasilkan. Setelah ditelaah selanjutnya akan direvisi oleh peneliti sehingga akan menghasilkan prototipe II. Dari prototipe II akan dilakukan validasi oleh ketiga ahli tersebut dengan tujuan untuk mengetahui tingkat validitas dari buku ajar. Kemudian dilanjutkan dengan uji coba yang dilakukan secara terbatas kepada peserta didik. Dari hasil tersebut akan dilanjutkan dengan proses analisis data untuk mengetahui tingkat validitas dari para ahli dan respon peserta didik berupa laporan pengembangan buku ajar. Tahap terakhir atau tahap keempat yaitu penyebaran (disseminate), tahap ini digunakan untuk melakukan penyebaran terhadap buku ajar. Namun penyebaran tidak dilakukan karena tujuan dari penelitian hanya untuk memenuhi kebutuhan subjek penelitian tanpa ada maksud untuk menyebarluaskan karena terbatasnya waktu dan juga biaya yang dimiliki.

Para ahli yang menjadi subjek uji coba yaitu satu dosen p dari Fakultas Ekonomi dan satu guru dari SMK Negeri 1 Kalitengah Lamongan sebagai ahli materi. Selanjutnya satu dosen Bahasa Indonesia dari Fakultas Bahasa dan Seni sebagai ahli bahasa, dan satu dosen Teknologi Pendidikan dari Fakultas Ilmu Pendidikan sebagai ahli grafis.

Eksploitasi data terdiri dari data kualitatif dan data kuantitatif. Data kualitatif didapatkan berdasarkan hasil telaah atas produk buku ajar dari ketiga ahli. Data kuantitatif didapat dari proses validasi oleh para ahli dan disajikan dalam lembar validasi yang kemudian diolah dengan berpedoman pada skala likert.

Hasil atas validasi dari para ahli selanjutnya akan dianalisis dengan menggunakan skala likert berdasarkan pada tabel berikut.

Tabel 1. Penilaian Skala Likert Untuk Validasi

\begin{tabular}{c|c}
\hline Kriteria & Skor \\
\hline Sangat Baik & 5 \\
\hline Baik & 4 \\
\hline Sedang & 3 \\
\hline Tidak Baik & 2 \\
\hline Sangat Tidak Baik & 1 \\
\hline
\end{tabular}

Sumber: Riduwan (2016)

Menghitung data pada lembar validasi dan merubah bentuk perhitungan menjadi presentase dengan rumus berikut.

p-ISSN 2337-571X | e-ISSN 2541-562X 
Tabel 2. Perhitungan Skor Penilaian Kelayakan

Presentase kelayakan

$=\underline{\text { Jumlah skor keseluruhan } \mathrm{x} 100 \%}$

Skor maksimal

Sumber: Riduwan (2016)

Interpretasi skor penilaian kelayakan buku ajar dengan pedoman sebagai berikut.

Tabel 3. Ketentuan Interpretasi Kelayakan

\begin{tabular}{c|c}
\hline Presentase & Kriteria Interpretasi \\
\hline $0 \%-20 \%$ & Sangat Tidak Layak \\
\hline $21 \%-40 \%$ & Tidak Layak \\
\hline $41 \%-60 \%$ & Cukup Layak \\
\hline $61 \%-80 \%$ & Layak \\
\hline $81 \%-100 \%$ & Sangat Layak \\
\hline
\end{tabular}

Sumber: Riduwan (2016)

Kesimpulan dari uraian tersebut maka buku ajar dinyatakan layak apabila memperoleh rentang presentase $\geq 61 \%$.

\section{Hasil dan Pembahasan}

Penelitian dilakukan dengan mengaplikasikan model 4-D tanpa penyebaran (disseminate). Tahap pertama adalah tahap pendefinisian (define). Tahap ini digunakan untuk menganalisis berbagai permasalahan yang terjadi di sekolah. Pada analisis ujung depan diperlihatkan keadaan bahwa dalam kegiatan pembelajaran yang terjadi di kelas XI Perbankan dan Keuangan Mikro di SMK Negeri 1 Kalitengah Lamongan pada mata pelajaran Akuntansi Perbankan belum tersedia bahan ajar sebagai pendukung kegiatan pembelajaran berdasarkan Kurikulum 2013 Revisi. Dalam pelaksanaan kegiatan pembelajaran di kelas, pendidik menggunakan buku ajar berupa LKS terbitan lama. Dalam LKS tersebut uraian materi yang termuat sangat singkat, soal-soal latihan masih bersifat biasa bukan HOTS. Metode penyampaian materi yang digunakan oleh pendidik adalah dengan cara ceramah sehingga menjadikan peserta didik cenderung pasif.

Setelah analisis ujung depan, maka langkah berikutnya adalah melakukan analisis terhadap peserta didik. Analisis peserta tersebut bertujuan untuk menganalisis karakteristik para peserta didik. Peserta didik di kelas XI Perbankan dan Keuangan Mikro SMK Negeri 1 Kalitengah Lamongan secara usia sudah mampu untuk beradaptasi dengan penerapan Kurikulum 2013. Peserta didik Dalam pelaksanaan pembelajaran peserta didik membutuhkan ilustrasi yang sesuai dengan materi yang dipelajari dengan tujuan agar mereka mampu secara jelas dan mudah dalam memahami materi. Hal tersebut dikarenakan belum tersedianya buku ajar yang selaras dengan pengimplementasian kurikulum yang berlaku.

p-ISSN 2337-571X | e-ISSN 2541-562X

(C) 2020 Edunomic: Jurnal Ilmiah Pendidikan Ekonomi Fakultas Keguruan dan Ilmu Pendidikan 
Analisis tugas yang dilakukan memiliki tujuan membantu peserta didik untuk menguasai isi dari materi yang tersedia dalam buku ajar. Rangkaian tersebut disusun berdasarkan sintak pada pendekatan scientific approach (5M). Analisis ini sebagai penentu dalam pembuatan tugas yang kemudian akan dikerjakan atau diselesaikan oleh peseta didik. Dalam buku ajar Akuntansi Perbankan berisi tujuh kompetensi dasar yaitu dimulai KD 3.1 KD 3.7 dalam satu semester. Alokasi waktu kegiatan pembelajaran adalah 3 x 45 menit (4x pertemuan) pada setiap kompetensi dasar yang ada. Tugas peserta didik adalah memahami kompetensi dasar, tujuan pembelajaran, uraian materi yang dilengkapi dengan tambahan konten sebagai tambahan referensi. Sesuai dengan penyusunannya pada buku ajar Akuntansi Perbankan berbasis pendekatan saintifik pada fase pengamatan, peserta didik diminta untuk mengamati isi materi yang disampaikan melalu media power point dan atau bentuk lainnya. Selanjutnya terdapat studi kasus pada fase menalar yang harus diselesaikan peserta didik dalam bentuk kelompok. Sedangkan untuk soal evaluasi berbentuk pilihan ganda dan uraian yang harus diselesaikan oleh peserta didik secara individu. Berikutnya adalah analisis konsep yaitu berupa identifikasi terkait konsep yang disajikan dalam buku ajar. Pada analisis konsep ini berupa peta konsep awal bab materi dan kompetensi dasar yang akan termuat dalam buku ajar. Adapun materi yang termuat sesuai dengan kompetensi dasar meliputi KD 3.1 Perbedaan akuntansi bank dengan akuntansi keuangan; KD 3.2 Persamaan dasar akuntansi bank; KD 3.3 Mekanisme debet dan kredit pada perbankan; KD 3.4 Akuntansi tabungan; KD 3.5 Akuntansi giro; KD 3.6 Akuntansi deposito; KD 3.7 Akuntansi kredit.

Langkah berikutnya adalah perumusan pada tujuan pembelajaran. Yang kemudian diselaraskan dengan Kompetensi Dasar yang dibuat pada analisis konsep. Perumusan tersebut dijadikan sebagai dasar dalam menyusun materi beserta soal evaluasi buku ajar Akuntansi Perbankan.

Kemudian adalah tahap perancangan (design). Tahap yang bertujuan untuk membuat suatu rancangan awal dari buku ajar Akuntansi Perbankan berbasis pendekatan scientific approach. Tahap ini diawali dengan penyusunan format yang berdasarkan pada pedoman BSNP dengan sintak scientific approach atau 5M dan dilanjutkan dengan membuat desain awal buku. Desain awal buku ini meliputi bagian pendahuluan yaitu berupa kover, lembar judul, kata pengantar, daftar isi, gambar, dan tabel, KI-KD, tujuan akhir. Bagian isi buku terdiri dari kompetensi dasar, tujuan pembelajaran, peta konsep, uraian kegiatan, konten science window sebagai konten yang berisi tentang pengetahuna baru atau update, konten mini quiz berupa pertanyaan yang sesuai dengan materi pada kompetensi dasar yang dibahas, konten key point adalah konten tentang poin-poin penting di setiap materi, konten $Q R$ code sebagai tautan untuk mengakses materi yang serupa , rangkuman materi pada setiap bab, soal evaluasi berbasis HOTS berbentuk pilihan ganda dan uraian. Daftar pustaka, glosarium, profil penulis, dan rangkuman singkat buku sebagai sampul belakang terletak pada bagian akhir.

Desain awal buku ajar ini menghasilkan prototipe I. Menurut Prastowo (2015) standar utama penyusunan buku ajar di Indonesia adalah Badan Standar Nasional Pendidikan (BSNP). Buku ajar Akuntansi Perbankan yang dikembangkan ini ukuran dan bentuk buku ajar serta ukuran dan bentuk huruf Akuntansi Perbankan berpedoman pada standar BSNP 
(2014a). Buku ajar Akuntansi Perbankan yang dikembangkan berukuran $210 \mathrm{~mm}$ x $297 \mathrm{~mm}$ (A4) dengan bentuk vertikal untuk pendidikan SMA/MA/SMK/MAK. Kemudian buku ajar Akuntansi Perbankan ini menggunakan ukuran huruf 10Pt-11Pt dengan bentuk huruf serif (berkaitan), yaitu Book Atique dan Century yang sesuai untuk pendidikan SMA/MA/SMK/MAK.

Pada tahap pengembangan (develop), prototipe I yang dibuat kemudian akan dilakukan telaah oleh para ahli yang kemudian akan memberikan masukan terhadap buku ajar. Kemudian atas masukan serta penilaian yang diterima, maka selanjutnya akan direvisi oleh peneliti dan menghasilkan prototipe II. Dari prototipe II akan dinilai tingkat validitas atau tingkat kelayakan dari buku ajar.

Berikut adalah tabel hasil telaah dari para ahli.

Tabel 4. Hasil Telaah Ahli Materi

\begin{tabular}{lll}
\hline No. & Aspek & Presentase \\
\hline 1. & Kelayakan isi & Hasil telaah dari ahli materi \\
& menunjukkan bahwa dalam dimensi \\
& pengetahuan untuk cakupan materi \\
& sudah lengkap dan luas. Sesuai \\
& dengan perkembangan ilmu dan \\
& dengan dilengkapi dengan contoh- \\
& contoh konkrit. Cukup terampil \\
& dalam menyajikan materi dengan \\
& menggunakan karakteristik kegiatan \\
& $5 \mathrm{M}$ sesuai dengan pendekatan \\
& saintifik. \\
& Materi yang disajikan konsisten \\
& sesuai dengan kompetensi dasar \\
& serta di lengkapi dengan ilustasi \\
& kegiatan pendekatan saintifik serta \\
Kelayakan & dilengkapi dengan latihan soal dan \\
& soal yang berbasis HOTS. Terdapat \\
& tambahan konten yang dapat \\
& membantu peserta didik untuk \\
& menggali informasi. \\
& \\
&
\end{tabular}

Sumber: data diolah oleh peneliti (2020)

Tabel 5. Hasil Telaah Ahli Bahasa

\begin{tabular}{lll}
\hline No. & Aspek & Presentase \\
\hline 1. & Kelayakan & $\begin{array}{l}\text { Hasil telaah menunjukkan bahwa } \\
\text { penggunaan bahasa setaraf daya }\end{array}$ \\
\hline
\end{tabular}

p-ISSN 2337-571X | e-ISSN 2541-562X

(C) 2020 Edunomic: Jurnal Ilmiah Pendidikan Ekonomi

Fakultas Keguruan dan Ilmu Pendidikan 


\begin{tabular}{ll}
\hline kebahasaan & pikir peserta didik. Materi \\
& disampaikan sangat bagus, tetapi \\
ada kalimat yang belum tepat dan & terdapat istiah yang tidak baku \\
& . Bahasa yang digunakan juga \\
& memberikan motivasi. Perlu \\
& adanya perbaikan dalam penulisan \\
& nama ilimah/asing.
\end{tabular}

Sumber: data diolah oleh peneliti (2020)

Tabel 6. Hasil Telaah Ahli Grafis

\begin{tabular}{lll}
\hline No. & Aspek & Presentase \\
\hline 1. & Kelayakan & Telaah dari ahli grafis menunjukkan \\
kegrafikan & hasil bahwa perlu adanya beberapa \\
& perbaikan pada desain sampul \\
& depan, penggunaan gambar pada \\
& buku harus formal, pembuatan tabel \\
& yang tidak konsisten pada setiap \\
& bab. Setelah dilakukan perbaikan, \\
& penelaah menyatakan bahwa produk \\
& buku ajar sudah bagus dan telah \\
& memenuhi seluruh prinsip serta \\
& layak untuk digunakan sebagai \\
& sumber belajar.
\end{tabular}

Sumber: data diolah oleh peneliti (2020)

\section{Kelayakan Buku Ajar}

Kelayakan terhadap buku ajar Akuntansi Perbankan berasal dari hasil validasi oleh ketiga ahli berdasarkan lembar validasi yang kemudian akan diolah dengan berpedoman pada skala likert sebagai dasar atas kelayakan produk buku ajar Akuntansi Perbankan yang dikembangkan. Buku ajar dinyakatan valid atau layak digunakan jika memperoleh rentang presentase $>61 \%$. Berikut disajikan tabel atas hasil validasi.

Ahli materi untuk telaah dan validasi buku ajar Akuntansi Perbankan diperoleh dari salah satu dosen dari Fakultas Ekonomi yaitu Rochmawati, S.Pd., M.Ak dan satu guru pengajar dari SMK Negeri 1 Kalitengah Lamongan yaitu Webbyani Kartikasari, M.Pd dengan rekapitulasi yang disajikan pada tabel berikut. 
Tabel 7. Hasil Validasi Ahli Materi

\begin{tabular}{lll}
\hline No. & Aspek & Presentase \\
\hline 1. & Dimensi Pengetahuan & $93,32 \%$ \\
2. & Dimensi Keterampilan & $86,67 \%$ \\
3. & Teknik Penyajian & $100 \%$ \\
4. & Pendukung Penyajian Materi & $91,42 \%$ \\
5. & Penyajian Pembelajaran & $90 \%$ \\
6. & Kelengkapan Penyajian & $100 \%$ \\
Rata-rata Presentase & $93,56 \%$ \\
Kategori & Sangat Layak \\
\hline
\end{tabular}

Sumber: data diolah oleh peneliti (2020)

Hasil validasi ahli materi disajikan pada tabel dengan rata-rata presentase 93,56\% dan termasuk dalam kategori sangat layak. Pada komponen kelengkapan penyajian, buku ajar akuntansi perbankan ini disajikan dengan pendekatan saintifik yang tercakup dalam kegiatan 5M. Selain itu pada setiap bab dilengkapi dengan contoh soal. Buku ajar akuntansi perbankan dilengkapi dengan berbagai konten yang dapat membantu peserta didik dalam belajar. Sehingga berdasarkan hasil dari analisis ahli materi, apabila diinterpretasikan berdasarkan skala likert maka buku ajar akuntansi perbankan ini sangat layak dipergunakan dalam kegiatan pembelajaran.

Ahli bahasa adalah dosen dari Fakultas Bahasa dan Seni yaitu Dr. Ririe Rengganis, M.Hum dengan hasil rekapitulasi sebagai berikut.

Tabel 8. Hasil Validasi Ahli Bahasa

\begin{tabular}{llrl}
\hline No. & Aspek & Presentase \\
\hline 1. & Kesesuaian & dengan & $100 \%$ \\
& $\begin{array}{l}\text { Perkembangan } \\
\text { Peserta }\end{array}$ & \\
& Didik & & \\
2. & Keterbacaan & $100 \%$ \\
3. & Kemampuan & Memberikan & $100 \%$ \\
& Motivasi & \\
4. & Kelugasan & $80 \%$ \\
5. & Koherensi dan Keruntutan & $100 \%$ \\
& Alur Pikir & \\
6. & Kesesuaian dengan Bahasa & $80 \%$ \\
& Indonesia & \\
7. & Pengunaan Istilah dan & $86,6 \%$ \\
& Simbol/Lambang & \\
\hline
\end{tabular}

p-ISSN 2337-571X | e-ISSN 2541-562X

(C) 2020 Edunomic: Jurnal Ilmiah Pendidikan Ekonomi Fakultas Keguruan dan Ilmu Pendidikan 


\begin{tabular}{ll} 
Rata-rata Presentase & $92,37 \%$ \\
Kategori & Sangat Layak \\
\hline Sumber: data diolah oleh peneliti (2020) &
\end{tabular}

Dari ahli bahasa menunjukkan hasil rata-rata presentase $92,37 \%$ dan termasuk kategori sangat layak. Hasil tersebut diperoleh karena penyesuaian penggunaan bahasa dalam buku ajar akuntansi perbankan. Tingkat keterbacaan yang bagus serta keruntutan alur berpikir yang terdapat dalam buku ajar akuntansi perbankan sehingga peserta didik terbantu menafsirkan materi.

Telaah dan validasi ahli grafis diperoleh dari dosen dari jurusan Kurikulum dan Teknologi yaitu Dr. Hari Sugiharto S., M.Si dengan rekapitulasi berikut.

Tabel 9. Hasil Validasi Ahli Grafis

\begin{tabular}{lll}
\hline No. & Aspek & Presentase \\
\hline 1. & Ukuran Buku & $100 \%$ \\
2. & Desain Kulit Buku & $97,3 \%$ \\
3. & Desain Isi Buku & $98,75 \%$ \\
4. $\quad$ Ilustrasi Isi Buku & $96,5 \%$ \\
Rata-rata Presentase & $98,1 \%$ \\
Kategori & Sangat Layak \\
\hline
\end{tabular}

Sumber: data diolah oleh peneliti (2020)

Validasi dari ahli grafis menunjukkan hasil rerata 98,1\%. Keharmonisan pada pola dan ilustrasi isi buku membantu peserta didik dalam memahami buku ajar akuntansi perbankan. Unsur tata letak yang terdapat dalam buku ajar akuntansi perbankan disajikan secara utuh dari awal hingga akhir sesuai dengan kompetensi dasar.

\section{Simpulan}

Buku ajar Akuntansi Perbankan dengan pendekatan saintifik dikembangkan dengan model 4D. Penelitian yang dilakukan ini tidak sampai tahap penyebaran karena terbatasnya waktu serta biaya peneliti. Kelayakan buku ajar Akuntansi Perbankan diperoleh dari hasil validasi oleh ketiga ahli sebagai validator. Berdasarkan kelayakan pada lembar validasi, maka dapat ditarik kesimpulan bahwa buku ajar Akuntansi Perbankan termasuk kategori sangat layak atau sangat valid untuk digunakan.

\section{Referensi}

Agustin Nur Raafi, R., \& Hakim, L. (2018). Pengembangan Buku Ajar Berbasis Saintifik Pada Mata Pelajaran Produk Syariah Semester I Kelas Xi Perbankan Syariah Di Smk Negeri 2 Mojokerto. Jurnal Pendidikan Akuntansi (Jpak), 6(2).

Arlianty, W. N., Febriana, B. W., \& Diniaty, A. (2017). An Analysis Of Learning Process 
Based On Scientific Approach In Physical Chemsitry Experiment. Aip Conference Proceedings, 1823(March). Https://Doi.Org/10.1063/1.4978157

Daryanto. (2014). Pendekatan Pembelajaran Saintifik Kurikulum 2013. Yogyakarta: Gava Media.

Firman, Baedhowi, \& Murtini, W. (2018). The Effectiveness Of The Scientific Approach To Improve Student Learning Outcomes. International Journal Of Active Learning, 3(2), 86-91. Retrieved From Http://Journal.Unnes.Ac.Id/Nju/Index.Php/Ijal\%0athe

Hapsari, Ornela; Hariyadi, Sugeng; Prihastuty, R. (2014). Pengaruh Iklim Sekolah Terhadap Kedisiplinan Belajar Siswa Kelas Vii Di Smp Teuku Umar Semarang. Intuisi Jurnal Ilmiah Psikologi, 6(1).

Indriyani, S., \& Hakim, L. (2019). Pengembangan Buku Ajar Berbasis Saintifik Pada Mata Pelajaran Akuntansi Perbankan Syariah Kelas Xii Semester Ii Smk Negeri 2 Kota Mojokerto. Jurnal Pendidikan Akuntansi (Jpak), 7(2), 310-314.

Kemendikbud. (2014). Peraturan Menteri Pendidikan Dan Kebudayaan. 103.

Ma'sum, A. R. (2019). Pengembangan Bahan Ajar Berbasis Saintifik Sebagai Suplemen Mata Pelajaran Praktikum Akuntansi Lembaga / Instansi Pemerintah Kelas Xi Materi Akuntansi Desa Pengembangan Bahan Ajar Berbasis Saintifik Sebagai Suplemen Mata Pelajaran Praktikum Akuntansi Lemb. Jurnal Pendidikan Akuntansi, 7, 434-441.

Prihatin Sulistyowati , Novita Martika Putri. (2018). Pengembangan Bahan Ajar Modul Berbasis Contextual Teaching And Learning ( Ctl ) Kelas Iv Tema 3 Subtema 13 , Malang, U. K.1-6.

Margana, M., \& Widyantoro, A. (2017). Developing English Textbooks Oriented To Higher Order Thinking Skills For Students Of Vocational High Schools In Yogyakarta. Journal Of Language Teaching And Research, 8(1), 26. Https://Doi.Org/Https://Doi.Org/10.17507/Jltr.0801.04

Masithoh, D. (2018). Teachers' Scientific Approach Implementation In Inculcating The Students' Scientific Attitudes. Jurnal Prima Edukasia, 6(1), 32. Https://Doi.Org/10.21831/Jpe.V6i1.14282

Mei, Y., Yunos, J., Othman, W., Hassan, R., \& Tze, T. (2012). The Needs Analysis Of Learning Higher Order Thinking Skills For Generating Ideas. 59, 197-203. Https://Doi.Org/10.1016/J.Sbspro.2012.09.265

Mulyasa. (2018). Implementasi Kurikulum 2013 Revisi. Jakarta: Bumi Aksara.

Mulyatiningsih, E. (2013). Metode Penelitian Terapan Bidang Pendidikan. Bandung: Alfabeta.

Muqodas, R. Z., Sumardi, K., \& Berman, E. T. (2015). Desain Dan Pembuatan Bahan Ajar Berdasarkan Pendekatan Saintifik Pada Mata Pelajaran Sistem Dan Instalasi p-ISSN 2337-571X | e-ISSN 2541-562X (C) 2020 Edunomic: Jurnal Ilmiah Pendidikan Ekonomi Fakultas Keguruan dan Ilmu Pendidikan 
Refrigerasi. 2(1), 106-115.

Nasution. (2013). Berbagi Pendekatan Dalam Proses Belajar Mengajar. Jakarta: Pt. Bumi Aksara.

Pertiwi, D. R. (2019). Pengembangan Bahan Ajar Akuntansi Perbankan Dan Keuangan Mikro Berbasis Pendekatan Saintifik Kelas Xi Perbankan Dan Keuangan Mikro Smk Negeri 1 Jombang. 7(2), 182-188.

Prastowo, A. (2015). Panduan Kreatif Membuat Bahan Ajar Inovatif. Yogyakarta: Diva Press.

Puspita Ratih, N., \& Hakim, L. (2018). Pengembangan Buku Ajar Berbasis Pendekatan Saintifik Sebagai Bahan Ajar Mata Pelajaran Akuntansi Perbankan Syariah Pada Siswa Smk Kompetensi Keahlian Perbankan Syariah. Jurnal Pendidikan Akuntansi (Jpak), $6(2)$.

Putra, N. S. R. (2020). Pengembangan Bahan Ajar Mata Pelajaran Akuntansi Perbankan Dan Keuangan Mikro Berbasis Contextual Teaching And Learning (Ctl). Edunomic, 8(2). Https://Doi.Org/10.33603/Ejpe.V8i2.3677

Riduwan. (2016). Skala Pengukuran Dan Variabel-Variabel Penelitian. Bandung: Alfabeta.

Sugiyono. (2018). Metode Penelitian Kuantitatif, Kualitatif, Dan R\&D. Bandung: Alfabeta.

Trianto. (2015). Mendesain Model Pembelajaran Inovatif, Progresif, Dan Kontekstual. Jakarta: Prenadamedia Group.

Undang-Undang No. 20 Tahun 2003. (2003). Uu No. 20 Tahun 2003. 147-173.

Vitasari, Dea; Rohayati, S. (2018). Pengembangan Lembar Kegiatan Peserta Didik ( Lkpd ) Berbasis Pendekatan Saintifik Pada Mata Pelajaran Administrasi Pajak Kelas Xi Di Smk Negeri Mojoagung Pengembangan Lembar Kegiatan Peserta Didik ( Lkpd ) Berbasis Pendekatan Saintifik Pada Mata Pelajaran. Jurnal Pendidikan Akuntansi, 6(2).

Wulandari, T. N. (2019). Pengembangan Lembar Kegiatan Peserta Didik ( Lkpd) Berbasis Higher Order Thinking Skills ( Hots ) Pada Mata Pelajaran Akuntansi Perbankan Kelas Xi Perbankan Di Smk Try Novita Wulandari Susanti. 07, 347-352. 